\title{
Visualisasi Matriks Biofilm Escherichia coli dengan Media Bacteriological Peptone, Sucrose dan Ethanol
}

\author{
Dwi Marlina ${ }^{1}$, Mala Kurniati ${ }^{2}$, Fauzan Hamid ${ }^{3}$, Fivi Larasathi ${ }^{4}$, Febtri Irnawita ${ }^{5}$ \\ 1,2,3,4,5 Fakultas Kedokteran, Universitas Malahayati Lampung, Indonesia \\ Email: zilan_zalila2008@yahoo.com
}

\begin{abstract}
Visualization of Escherichia coli Biofilm which is Cultured in Bacteriological Peptone, Sucrose and Ethanol. Escherichia coli is a bacterium which is found in the intestines as a normal flora. In 2011, WHO (World Health Organization) showed that $14 \%$ of Children's Deaths that is caused by Escherichia coli. In extreme conditions, Escherichia coli can create biofilms,

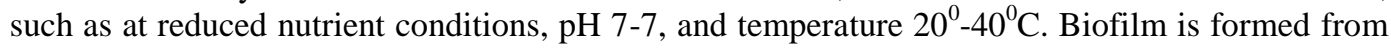
Escherichia coli that is contained EPS (extracellular polymeric substances). It has function as protector of bacterial cells. EPS contains glucuronic acid and Manosa. The formation of Biofilm can extend treatment process of patients and can cause chronic and recurrent inflammatory process. Aims this study is to know the characteristics of Escherichia coli biofilm and visualize the biofilm produced using sucrose $2 \%, 5 \%$ ethanol and $25 \%$ Peptone bacteriological in a culturing process. This study is an experimental and use microorganisms Escherichia coli which is cultured in Laboratory of Microbiology, University of Lampung and used Scanning Electron Microscope (SEM) for visualization and Aurum $(\mathrm{Au})$ for coating. Based on the findings of observation under SEM (Scanning Electron Microscope), Escherichia coli has a thick layer as a biofilm, particularly in Bacteriological Peptone 25\%. Therefore, bacterial cell colonies sheltered perfect from various antibacterial. Conclusion: Escherichia coli perfectly can create biofilms. For advanced research, can find the inhibitor of biofilm and destroyer of Escherichia coli cells.
\end{abstract}

Keywords: Biofilm, Escherichia coli, EPS

\begin{abstract}
Abstrak: Visualisasi Matriks Biofilm Escherichia coli dengan Media Bacteriological Peptone, Sucrose dan Ethanol. Escherichia coli adalah bakteri yang banyak ditemukan di usus besar manusia sebagai flora normal. Pada tahun 2011, data WHO (World Health Organization) menunjukan bahwa 14\% kematian pada anak disebabkan oleh bakteri Escherichia coli. Biofilm sebagai salah satu faktor virulensi yang terdapat dalam Esherichia coli dapat terbentuk pada kondisi nutrisi yang sedikit, $\mathrm{pH}$ netral yaitu 7-7.5, dan temperatur yang merugikan yaitu kisaran suhu $20^{\circ}-40^{\circ} \mathrm{C}$. Biofilm mengandung EPS (Extracellular Polymeric Substance) yang berfungsi untuk melekatkan diri dan melindungi sel-sel bakteri tersebut. EPS yang terbentuk berjumlah lebih banyak serta mengandung asam glukuronat dan manosa. Pembentukan biofilm mampu memperpanjang masa pengobatan pasien sehingga banyak kerugian yang ditimbulkan baik materi maupun non-materi. Tujuan penelitian ini adalah untuk mengetahui karakteristik matriks biofilm dari bakteri Escherichia coli dan memvisualisasikan biofilm yang dihasilkan oleh Escherichia coli dalam tiga variasi media yaitu sukrosa $2 \%$, ethanol 5\% dan Bacteriological Peptone $25 \%$. Penelitian ini merupakan eksperimen, dengan menggunakan mikroorganisme Escherichia coli yang yang dikembangbiakkan di Laboratorium Mikrobiologi FMIPA Universitas Lampung dan pengamatan Escherichia coli menggunakan Scanning Electron Microscope (SEM) dengan menggunakan Aurum ( $\mathrm{Au}$ ) sebagai pelapis sebelum pengamatan dibawah SEM. Berdasarkan hasil pengamatan dibawah SEM (Scanning Electron Microscope), biofilm Escherichia coli yang dibudayakan pada media Bacteriological Peptone 25\% mampu membentuk lapisan atau film yang sangat tebal sehingga koloni sel bakteri tersebut terlindung secara sempurna dari beragam antibakteri. Kesimpulan: E.coli mampu membentuk biofilm yang sempurna. Tahap penelitian lanjutan diharapkan mampu menentukan penghambat biofilm Escherichia coli dan penghancur sel-sel Escherichia coli.
\end{abstract}

Kata kunci: Biofilm, Escherichia coli, EPS

Escherichia coli adalah bakteri yang banyak ditemukan di usus besar manusia sebagai flora normal. Escherichia coli dapat didefinisikan sebagai bakteri yang menyebabkan infeksi primer pada usus dan jaringan lain diluar usus misalnya diare pada anak dan infeksi saluran kemih. Pada tahun 2011, data WHO (World Health Organization) menunjukan bahwa 14\% kematian 
pada anak disebabkan oleh bakteri E.coli. Data yang diterima dari Kemenkes Republik Indonesia tahun 2010 terdapat kejadian luar biasa diare di 33 kecamatan dengan jumlah penderita 4.204 dengan kematian 73 orang. Oleh karena itu, Indonesia termasuk negara berkembang yang memiliki tingkat morbiditas dan mortalitas akibat penyakit diare yang cukup tinggi (Depkes RI, 2011).

Dalam keadaan ekstrim Esherichia coli mampu membentuk biofilm yang banyak. Keadaan ekstrim tersebut berupa nutrisi yang berkurang, $\mathrm{pH}$ netral yaitu 7-7.5, dan temperatur yang merugikan yaitu kisaran suhu $20^{\circ}-40^{\circ} \mathrm{C}$ (Mahon, et al., 2011). Biofilm yang terbentuk dari Esherichia coli mengandung EPS yang berfungsi untuk melekatkan diri dan melindungi sel-sel bakteri tersebut. EPS yang terbentuk berjumlah lebih banyak serta mengandung asam glukuronat dan manosa (Dewanti \& Wong, 1995). Peningkatan jumlah sel biofilm tergantung pada ketersediaan nutrisi pada media. Berkurangnya nutrisi menyebabkan terjadinya adaptasi Esherichia coli dengan membulatkan diri (rounding) dan mengecilkan bentuk dan volume (dwarfing). Dwarfing menyebabkan kenaikan hidrofobitas dan agregrasi sel sehingga terjadi peningkatan massa yang mempengaruhi peran gravitasi dalam transpors sel biofilm ke permukaan (Dewanti \& Wong, 1995).

Biofilm adalah kumpulan sel-sel bakteri yang melekat secara irreversibel pada suatu permukaan dan terbungkus dalam matriks EPS (Extracellular Polymeric Substance), memiliki struktur mikroskopis yang hanya bisa dilihat dengan mikroskop khusus. Apabila pertumbuhan biofilm ini subur dan cepat maka biofilm dapat dilihat dengan mata tanpa bantuan alat apapun.Biofilm yang dapat dilihat diantaranya plak gigi dan lapisan berlendir yang terdapat diatas permukaan luka. Pembentukan biofilm pada tubuh manusia berkontribusi dalam progresi penyakit infeksi akut menjadi kronis dan berulangnya suatu infeksi. Disamping itu juga, beberapa kriteria infeksi yang berasosiasi dengan biofilm adalah adherensi suatu bakteri, dan meningkatnya resistensi terhadap antibiotik dibandingkan infeksi bakteri dalam bentuk planktonik, dimana sifat-sifat tersebut pada akhirnya akan dapat menyebabkan infeksi yang kronik (Donlan, 2001).

Tanpa disadari biofilm sudah banyak mengkontaminasi berbagai peralatan implan medis, ventilator, peralatan dokter gigi, dan menjadi sumber dari infeksi pada manusia, hewan dan tumbuhan hingga saat ini.Oleh karena itu, adanya peningkatan jumlah infeksi kronik yang berhubungan dengan biofilm bukan merupakan hal yang mengejutkan dalam dunia kesehatan, dimana infeksi tersebut sulit diatasi dengan terapi antibiotic konvensional. Berdasarkan publikasi dari National Institute of Health, lebih dari $80 \%$ infeksi berhubungan dengan kehadiran biofilm.

Dari penjelasan diatas, terlihat bahwa pembentukan biofilm mampu memperpanjang masa pengobatan pasien sehingga banyak kerugian yang ditimbulkan baik materi maupun non-materi.Disamping itu juga, proses inflamasi kronik dan berulang yang ditimbulkan oleh biofilm tentu dapat memperburuk kondisi fisik dan juga mengurangi kualitas hidup dari pasien tersebut. Oleh karena itu, penelitian ini akan memvisualisasi karakter biofilm yang dihasilkan oleh E.coli dalam tiga variasi media, dengan pengharapan mampu memberikan informasi bagi penelitian selanjutnya untuk menentukan penghambat dari biofilm tersebut.

\section{METODE}

Penelitian ini merupakan eksperimen yang dilakukan di Laboratorium terpadu MIPA Universitas Lampung, dengan menggunakan sampel Escherichia coli koleksi Laboratorium Mikrobiologi Universitas Lampung.

\section{Alat dan Bahan}

Cawan biakan, ose, Bunsen, laminar, 6 wells, sentrifuge, micropipette, micro tube, human serum, bacteriological peptone (BP), ethanol, dan sukrosa.

\section{Persiapan E.coli}

1. Satu koloni dari Escherichia coli dimasukkan kedalam $200 \mu \mathrm{L}$ bakteriologi peptone. Konsentrasi bakteri diperkirakan $5 \times 10^{7}$ bakteri per $\mathrm{mL}$ (perhitungan: 1 koloni sebelumnya telah terbukti mengandung sekitar $10^{7}$ sel.

2. Kemudian tahap 1 disentrifugasi pada 4000 rpm selama 20 detik, buang cairannya dan tambahkan endapan yang terbentuk dengan $200 \mu \mathrm{L}$ sukrosa, ethanol atau bakteriologi peptone.

\section{Persiapan MRSA Biofilm}

$30 \mu \mathrm{L}$ human serum diletakkan di atas stuff kemudian dimasukkan ke dalam inkubator selama $\pm 30 \quad$ menit.Teteskan $20 \mu \mathrm{L}$ bakteri Escherichia coli dan diletakkan tepat diatas human serum, kemudian diinkubator selama 2 jam.Setelah 2 jam, tuangkan media BP, 
$\mathrm{BP}+$ ethanol $5 \%$ dan $\mathrm{BP}+$ sucrose $2 \%$ hingga menutupi seluruh permukaan.Biarkan di inkubator selama 48 jam (24 jam pertama harus ganti media $\mathrm{BP}, \mathrm{BP}+$ ethanol $5 \%$, dan $\mathrm{BP}+$ sucrose $2 \%$ ).

Persiapan Biofilm Escherichia coli untuk SEM

Bilas sampel biofilm dengan BP, kemudian keringkan sampel dengan merendam pada ethanol 70\%, 90\%, dan 98\%, masing-masing selama 10 menit. Letakkan sampel dalam desikator selama 5 hari kemudian hingga proses pengamatan di bawah SEM.

\section{HASIL}

Ada tiga jenis biofilm terbentuk dalam eksperimen ini. Pada jenis pertama biofilm ditunjukkan pada gambar 1 menunjukkan bahwa film ini diproduksi cukup tebal yaitu terlihat gumpalan yang sangat tebal dan banyak sel yang terlihat disana. Gambar 2 diambil dari pembesaran dan menunjukkan jumlah sel yang banyak dan film atau lapisan pelindung yang cukup banyak. Biofilm pada jenis kedua dan ketiga ditunjukkan pada gambar 3 dan 4. Gambar 3 adalah biofilm yang dibentuk oleh penggunaan media yang sama yaitu Bacteriological Peptone yang ditambahkan ethanol 5\% sedangkan gambar 4 adalah biofilm yang dibentuk oleh Bacteriological Peptone tetapi dilakukan penambahan sukrosa $2 \%$. Adanya penambahan ethanol 5\% dan sukrosa 2\% menunjukkan adanya sel-sel yang lebih bersih dari pengaruh gumpalan biofilm dan jumlah sel yang terbentuk lebih sedikit.

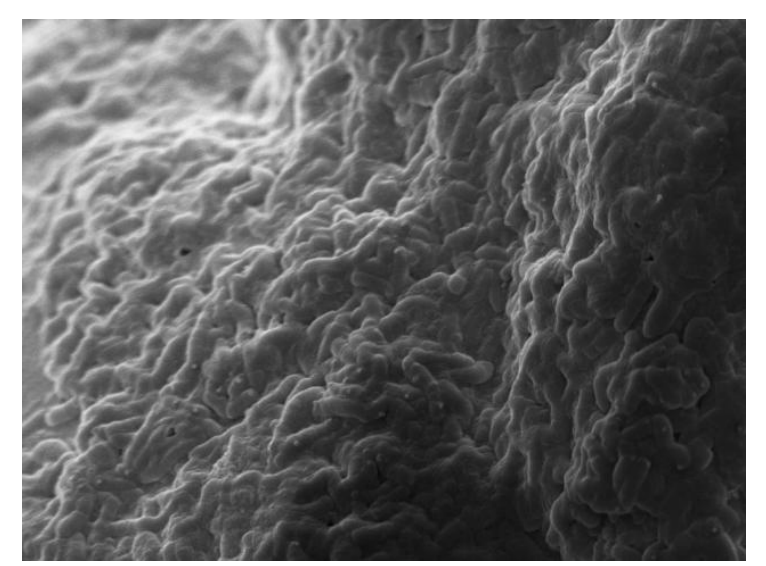

Gambar 1. Seluruh sel Escherichia coli dilapisi oleh suatu lapisan yang merupakan karakter dari biofilm

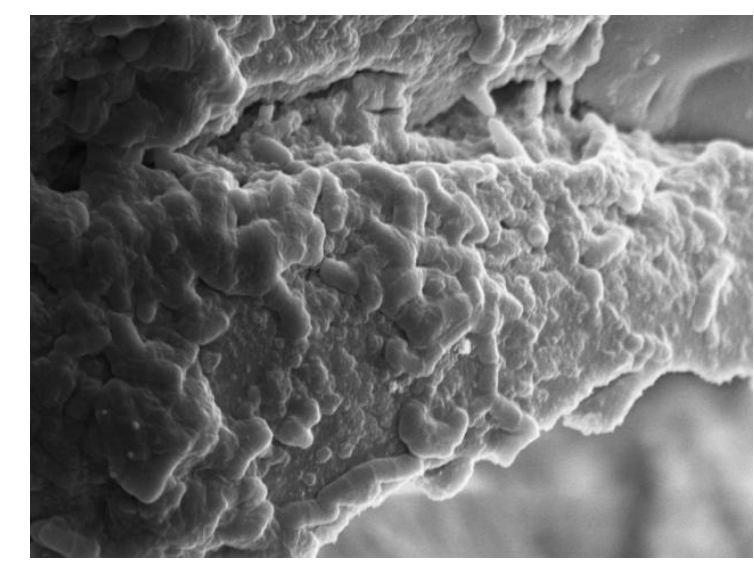

Gambar 2. Sel Escherichia coli dilapisi lapisan tebal yang sebagian besar merupakan EPS dan tampak lapisan pembungkus untuk setiap sel

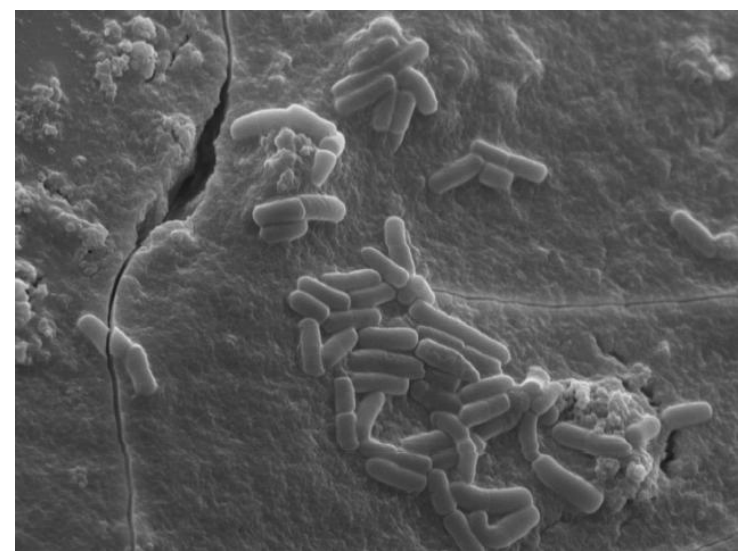

Gambar 3. Sel Escherichia coli pada media Bacteriological Peptone dengan penambahan ethanol 5\%; jumlah sel lebih sedikit dan lapisan yang melindungi koloni sel lebih bersih atau lebih tipis.

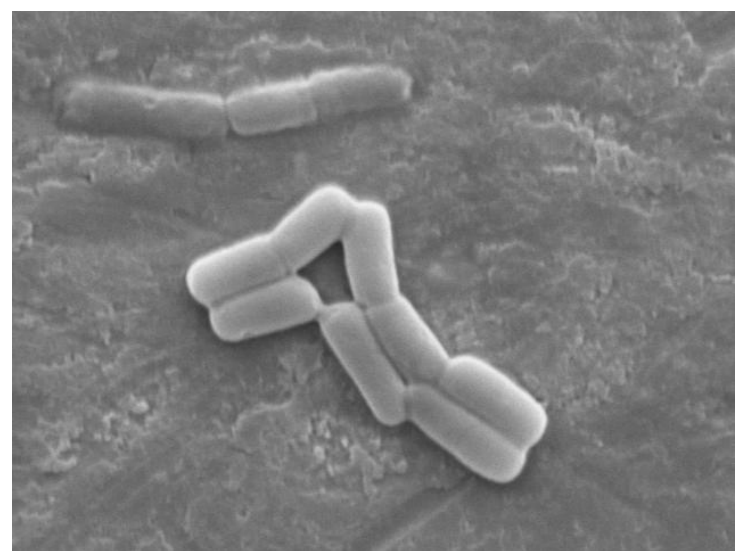

Gambar 4. Sel Escherichia coli pada media Bacteriological Peptone dengan penambahan sukrosa $2 \%$ lebih sedikit menghasilkan sel Escherichia coli dan lapisan pelindung (biofilm) dibandingkan jumlah sel pada gambar 3 


\section{PEMBAHASAN}

Dari ketiga macam jenis media yang digunakan pada proses pembentukan biofilm Escherichia coli, media Bacteriological Peptone murni mampu membuat Escherichia coli membentuk lapisan yang berisi kumpulan sel-sel bakteri yaitu Escherichia coli yang melekat secara irreversible pada suatu permukaan dan terbungkus dalam suatu matriks EPS (Extrapolisakarida) atau dikenal dengan biofilm. Hal ini disebabkan karena Bacteriological peptone merupakan enrichment media yang mengandung senyawa asam amino (unsur nitrogen) yang berfungsi untuk sintesis enzim, protein, dan asam nukleat. Ketika asam amino disintesis atau telah tersedia di media akan digunakan Escherichia coli untuk sintesis protein sehingga menghasilkan basa purin dan pirimidin. Kedua basa tersebut selanjutnya dapat dimanfaatkan oleh Escherichia coli untuk membentuk DNA dan RNA (Rachmadi, 2009). RNA membantu ribosom dalam proses sintesis protein sedangkan DNA memiliki dua jenis yaitu DNA kromosom dan DNA ekstrakromosom (plasmid) yang bermanfaat saat duplikat pada proses konjugasi. Plasmid tidak mengatur pertumbuhan dan metabolisme namun berfungsi sebagai pelindung terhadap antibiotik (resinten antibiotik), serta produksi enzim dan toksin (Stoodley, et al, 2002). Pada Escherichia coli terdapat gen wcaF yang mengatur pengeluaran acetyltransferase selama proses sintesis asam kolanik sehingga akan membuat biofilm menjadi matang (Donlan, 2002 \& Madigan, et al., 2006).

Karakter lain yang tampak pada biofilm Escherichia coli yaitu dari gambar 1 dan 2 terlihat bahwa adanya lapisan tebal yang melindungi koloni sel-sel Escherichia coli tetapi Escherichia coli diketahui sebagai bakteri gram negatif yang kandungan peptidoglikannya lebih sedikit dibandingkan dengan bakteri gram positif. Peptidoglikan berfungsi memproduksi polisakarida. Polisakarida itu merupakan bagian dari EPS sebagaimana kita ketahui bahwa EPS menjadi komponen utama untuk struktur dan fungsi pembentukan biofilm. Hal inilah yang mempengaruhi kualitas matriks biofilm Escherichia colisebagai bakteri gram negatif jika dibandingkan dengan matriks biofilm pada bakteri gram positif yang mempunyai ciri matriks biofilm yang tebal, antar sel yang perlekatannya sangat kuat dan menumpuk, serta ada terowongan yang sangat jelas terlihat. Ciri tersebut dapat dilihat pada gambar 5 yang merupakan hasil penelitian dari Dwi Marlina (2015) berjudul Can Melittin Treat Biofilm of MRSA (Methicillin
Resistant Staphylococcus aureus) tahun 2013 yang dilaksanakan di Laboratorium Universitas Curtin Australia.

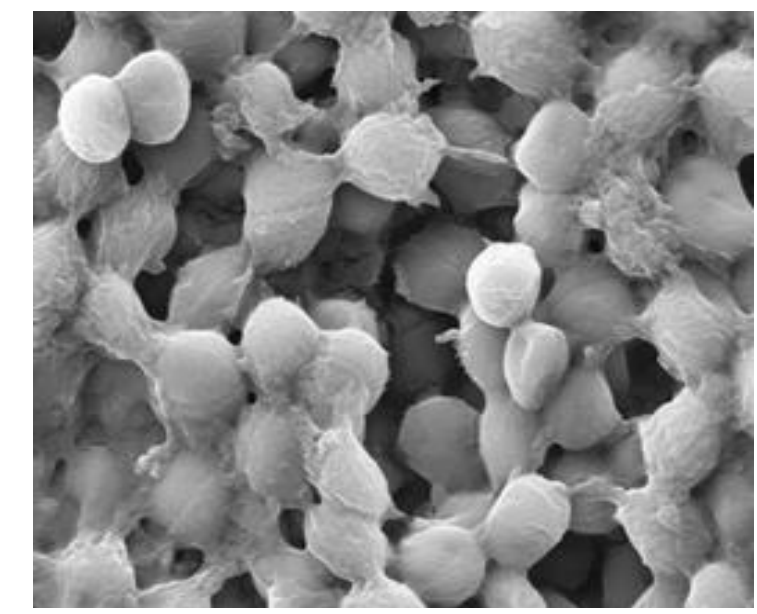

Gambar 5. Biofilm MRSA

Escherichia coli mempunyai flagel, dimana flagelnya berfungsi untuk mendapatkan nutrisi. Reseptor pada permukaan bakteri mampu mendeteksi nutrisi dalam lingkungan. Ketika sel sudah dekat dengan sumber nutrisi maka akan menghasilkan gradien (kemotaksis). Escherichia coli mampu mendeteksi gradien ini, menentukan arah orientasi untuk bergerak menuju sumber nutrisi, dan memutar flagela untuk berenang ke arah nutrisi tersebut. Jika bakteri ini mendeteksi senyawa kimia beracun, flagel akan berputar, memperlambat pergerakan dan berenang menjauh dari sumber racun untuk menuruni gradien konsentrasi. Maka dari itu alasan matriks biofilm tidak terjadi penumpukan dikarenakan Escherichia coli memiliki flagel dan flagel tersebut hanya mendekati sumber nutrisi yang berada dipermukaan bila itu bukan sumber nutrisi flagel Escherichia coliakan menjauh (Purwani, dkk., 2009).

Media Bacteriological peptone seperti penjabaran diatas mampu membentuk biofilm yang tebal, tetapi akan memberikan karakter biofilm yang berbeda ketika Bacteriological peptone ditambahkan dengan ethanol 5\% ataupun sukrosa $2 \%$. Karakter yang terbentuk berdasarkan hasil yang diperoleh yaitu pada gambar 3 dan 4 bahwa koloni sel Escherichia coli hanya memiliki lapisan pelindung atau biofilm yang sangat tipis. Hal ini terjadi karena sukrosa yang digunakan adalah gula yang umum dikonsumsi. Gula secara kimia mempunyai senyawa yang bersifat larut air. Gula akan menghambat pertumbuhan bakteri dengan cara mendehidrasi bakteri atau menyerap air yang dimiliki oleh bakteri tersebut sehingga bakteri akan mengalami penciutan (Winarno, 2008). Pada dasarnya keberadaan sukrosa dengan kandungan 2\% 
mempengaruhi pertumbuhan biofilm untuk memproduksi EPS. Peningkatan jumlah biofilm dipengaruhi oleh ketersediaan nutrisi pada media. Terbatasnya nutrien mengharuskan bakteri menyesuaikan diri dalam memperoleh sumber energi, misalnya terjadinya rounding (sel menjadi bulat) dan dwarfing (mengecil ukuran dan volume) pada morfologi sel bakteri (Sutarma, 2000). Sukrosa termasuk salah satu faktor yang mempengaruhi kualitas EPS dalam pembentukan biofilm. Sukrosa dengan rumus empiris $\mathrm{C}_{12} \mathrm{H}_{22} \mathrm{O}_{11}$ merupakan salah satu karbohidrat yang terdiri dari dua molekul yaitu glukosa dan fruktosa. Sukrosa mempunyai sifat yang sangat larut dalam air. Apabila ada peningkatan level sukrosa ternyata menyebabkan jumlah bakteri menurun karena perubahan lingkungan pertumbuhan bakteri. Penurunan jumlah bakteri diduga karena proporsi sumber karbon yang berlebih. Konsentrasi gula yang terlalu tinggi menyebabkan kondisi lingkungan menjadi hipertonik sehingga cairan dalam sel mikroorganisme mengalir keluar yang mengakibatkan terjadinya dehidrasi dan pengkerutan sel mikroorganisme (plasmolisis) (Maryana, 2014 \& P. Naves, et al., 2000).

Selain sukrosa, penurunan jumlah bakteri Escherichia coli memberikan perubahan saat mikrokoloni akan beradaptasi. Ini diakibatkan terbentuknya tahapan anaerob atau tanpa kadar oksigen sehingga jumlah bakteri yang tidak mampu beradaptasi pada lingkungan akan mengalami mortalitas yang tinggi dibandingkan bakteri yang mampu beradaptasi. Terbatasnya nutrien yang didapatkan terutama karbon dapat menyebabkan terhambatnya pertumbuhan beberapa jenis bakteri heterotrof. Bakteri heteretrof atau saprofit adalah bakteri yang hidup dengan memperoleh makanan zat organik (sampah, kotoran, bangkai) dari lingkungannya. Contoh bakteri heterotrof, yaitu Escherichia coli, Vibrio, Lactobacillus casei, Mycobacterium, Corynebacterium diphteriae, Bordetella pertusis, dan lain-lain. Oleh karena itu, sukrosa yang tinggi berpengaruh negatif terhadap pertumbuhan bakteri dan EPS yang dihasilkan (Sukenda, dkk., 2006, Tamime, 2006, \& Suciati, 2016).

EPS merupakan komponen terbesar dari biofilm yang terdiri dari karbohidrat dan non karbohidrat. Menurut penelitian tidak hanya EPS yang bekerja dalam pembentukan biofilm, ternyata terdapat asam kolanik yang sangat penting dalam pembentukan struktur tiga dimensi dan kedalaman biofilm Escherichia coli. Ini disebabkan asam kolanik yang bersifat negatif akan dinetralkan oleh proton permukaan sel bakteri sehingga proton dipermukaan makin banyak dan menumpukkan sel bebas lainnya. Asam kolanik tidak alami terikat pada permukaan melainkan ia hanya sebagai penentu ketebalan jaringan tiga dimensi biofilm.

Selain kehadiran sukrosa yang mampu membuat keberadaan biofilm Escherichia coli tipis, Ethanol juga mampu menciptakan kondisi yang tidak jauh berbeda. Hal ini disebabkan karena ethanol mampu menyebabkan tekanan osmotik media menjadi hipertonik. Hipertonik menyebabkan terjadinya perpindahan air yang terdapat pada biofilm ke media sehingga akan menyebabkan sel mengkerut. Selain itu, Escherichia coli merupakan bakteri gram negatif yang memiliki dua lapis membran yakni membran dalam (mengandung fosfolipid) dan membran luar (mengandung lipopolisakarida). Kedua membran mengandung komponen hidrofobik yang tak mampu larut dengan senyawa polar (air) namun kandungan ethanol $5 \%$ dalam bacteriological peptone $25 \%$ menyebabkan terlarutnya lipid sehingga membran tidak elastis lagi melainkan kaku/rigid dan bersih tanpa ada yang bergelombang. Serta mempengaruhi kerja $\mathrm{Mg}$ dan ATPase yang berada dalam membran untuk memproduksi ATP. Pada dasarnya, ethanol juga dapat meningkatkan produksi biofilm dengan cara merangsang respon Escherichia coli sehingga terjadi traskripsi gen (produksi selulosa). Formasi biofilm tergantung dari faktor pertumbuhan Escherichia coli. Escherichia coli menggunakan ethanol (hidrokarbon) sebagai sumber energi. Kemudian ethanol akan mengalami proses glikolisis untuk menghasilkan glukosa-6-fosfat selanjutnya akan langsung membentuk asam kolanik (penyusun matriks biofilm) atau akan diubah terlebih dahulu menjadi glukosa-1-fosfat yang selanjutnya akan membentuk sellulosa (penyusun matriks biofilm), tetapi kemampuan ethanol 5\% dalam bacteriological peptone untuk melarutkan lipid dari membran yang terdapat pada Escherichia coli sangatlah besar, sehingga mengakibatkan matriks biofilm mudah lepas.

Secara keseluruhan penelitian ini memvisualisasikan karakter matriks EPS biofilm yang dihasikan oleh Escherichia coli dengan masing-masing media yang telah digunakan. Karakter matriks biofilm itu sendiri banyak faktor yang mempengaruhinya mulai dari lingkungan ph, suhu, jenis bakteri, dan flagel yang dimiliki oleh bakteri. Secara keseluruhan biofilm Escherichia coli memiliki ciri khas yang bergantung pada nutrien yang mereka dapatkan. Informasi karakteristik matriks yang dibentuk oleh biofilm Escherichia coli dengan kombinasi media yang beragam ini maka akan 
mempermudah dalam menentukan penghambat pertumbuhan biofilm Escherichia coli.

\section{SIMPULAN}

Mikroorganisme Escherichia coli sebagai bakteri Gram negative mampu membentuk biofilm dengan karakter matriks yang sangat tebal tetapi tidak bertumpuk (tidak membentuk terowongan), sehingga hal ini akan lebih mempermudah untuk proses penghambatan sekaligus penghancuran biofilm beserta koloni sel yang terdapat dalam lapisan biofilm tersebut.

\section{DAFTAR PUSTAKA}

Dewanti, R., \& Wong, A. C. 1995. Influence of culture conditions on biofilm formation by Escherichia coli O157: H7. International journal of food microbiology, 26(2), 147164.

Departemen Kesehatan Republik Indonesia. 2011. Profil Kesehatan Indonesia 2010. Jakarta: Departemen Kesehatan Republik Indonesia.

Donlan, R. M. 2001. Biofilm formation: a clinically relevant microbiological process. Clinical Infectious Diseases, 33(8), 1387-1392.

Donlan, R. M. 2002. Biofilms: Microbial life on Surfaces. Emerging Infectious Diseases. 8: 881-890.

Madigan MT, Martinko JM, Brock TD. 2006. Brock Biology of Microorganism. 11th ED. New Jersey: Pearsom Prentice Hall. p:617619.

Marlina Dwi. Can Melittin Treat Biofilm of MRSA (Methicillin Resistant Staphylococcus aureus). Result \& Discussion. [Thesis]. Australia: Curtin University. p. 1-16;2015.

Mahon CR, Lehman DC, dan Manuselis, George. 2011. Text Book of Diagnostiv Microbiology. $\quad 4^{\text {th }}$ Edition. China: Sauders Elsevier.

Maryana Dwi. 2014. Pengaruh Penambahan Sukrosa Terhadap Jumlah Bakteri dan Kesamaan Whey Fermentasi dengan Menggunakan Kombinasi Lactobacillus plantarum dan Lactobacillus acidophilus. Tinjauan Pustaka. [Skripsi]. Makassar: Universitas Hasanuddin.

P. Naves, Leslie A, Roberto Kolter. 2000. Exopolysaccaride Production Is Required for Development of Escherichia coli K-12.

\section{SARAN}

Bagaimanapun, penelitian ini merupakan tahap awal dalam proses penentuan penghambat dari biofilm yang dibentuk oleh mikroorganisme Escherichia coli. Oleh karena itu disarankan untuk menambah variasi media untuk mendapatkan kondisi matriks biofilm yang lebih sempurna, sehingga penentuan penghambatan yang akan dilakukan dalam tahap penelitian selanjutnya mampu menetapkan konsentrasi maksimum dalam proses penghambatan biofilm tersebut.

Biofilm Architecture. Vol.182. No.12 .p : 3593-3596.

Purwani Eni, Hapsari Nur, Rauf Rusdin. 2009. Respon Hambatan Bakteri Gram Positif Dan Gram Negatif pada Ikan Nila (Oreochromis niloticus) yang Diawetkan dengan Ekstrak Jahe (Zingiber officinale). Jurnal Kesehatan ISSN 1979-7621, Vol. 2, No. 1.

Rachmadi Dedi. 2009. Peranan Probiotik pada Infeksi Saluran Kemih. http://pustaka.unpad,ac.id>2013/12.

(Diakses pada 13 Maret 2015).

Stoodley P, Sauer K, Davies DG, Costerton JW. 2002. Biofilms as complex differentiated communities. Annu Rev Microbiol; 56: 187-209.

Sutarma. 2000. Kultur Media Bakteri. Temu Teknis Fungsional non Peneliti. https://s3.amazonaws.com/academia.edu.d ocuments/44344445/ptek00-

8.pdf?AWSAccessKeyId=AKIAIWOWY YGZ2Y53UL3A\&Expires=1525238070\& Signature $=$ CE8Iuf39gMM0YkgXAq8kCb yVxq8\%3D\&response-contentdisposition=inline $\% 3 \mathrm{~B} \%$ 20filename\%3DP tek00.pdf (Diakses pada 25 Desember 2015).

Suciati A, Muntalif SB. 2013. Dinamika Pertumbuhan Mikroorganisme Yang Berperan Pada Degredasi Biowaste Dalam Reaktor Anaerob Tercurah. [Skripsi]. Bandung. Program Studi Teknik Lingkungan Fakultas Teknik Sipil dan Lingkungan, Institut Teknologi Bandung. http://ftsl.itb.ac.id (Diakses Pada 3 april 2016).

Sukenda, Hadi, P., \& Harris, E. 2006. Pengaruh pemberian sukrosa sebagai sumber karbon 
dan probiotik terhadap dinamika populasi bakteri dan kualitas air media budidaya udang vaname, Litopenaeus vannamei. Effect of Sucrose as Carbon Source and Probiotic Administrations on Bacterial Population Dinamic and Water Quality in White Shrimp, Litopenaeus vannamei Culture. Jurnal Akuakultur Indonesia. 5(2): 179-190
Tamime, A.Y. 2006. Fermented Milks. Blackwell: UK.

Winarno, F.G. 2008. Kimia Pangan dan Gizi. Edisi terbaru. Jakarta: Gramedia Pustaka Utama.

World Health Organization. 2011. Global Health Observatory: Child health. http://www.who.int/gho/child_health/en/in dex.html 